\title{
Dietary Protein-induced Changes of the Erythropoietin Level in Rat Serum ${ }^{\dagger}$
}

\author{
Ryuzo Sasaki, Hideki Ohnota, Shin-ichi Yanagawa \\ and Hideo CHIBA \\ Department of Food Science and Technology, Faculty of Agriculture, \\ Kyoto University, Kyoto 606, Japan
}

Received March 15, 1985

\begin{abstract}
Erythropoietin, a glycoprotein, is the primary regulator of erythropoiesis. The most convenient and sensitive assay for active erythropoietin is to measure its stimulatory effect on in vitro ${ }^{3} \mathrm{H}$ thymidine incorporation into DNA of erythropoietin-responsive cells. An attempt with this method to estimate the erythropoietin level in rat serum, however, was unsuccesful because of the presence of inhibitory substance(s) and non-erythropoietic factor(s) stimulating ${ }^{3} \mathrm{H}$-thymidine incorporation. Pretreatment of the serum by heating, extraction of erythropoietin from denatured-protein aggregates, and subsequent concentration of erythropoietin in the extract with alcohol precipitation made it possible to measure the serum erythropoietin levels. Rabbit anti-erythropoietin antibody was used for a quantitative estimation of erythropoietin in the concentrated extracts. Erythropoietin levels in sera of rats fed on varied amounts of casein for 7 days were measured with these procedures to find if the impairment of erythropoiesis upon protein deprivation was due to changes in the erythropoietin level. We found that the level in protein-deprived rats was less than $1 / 8$ that of $20 \%$ casein-fed rats, a level undetectable by the present assay, and that the serum erythropoietin increased as the protein content in the diet was increased up to $20 \%$, then leveled off. The erythropoietin in serum decreased rapidly after protein deprivation; the level at $12 \mathrm{hr}$ after deprivation began was about $1 / 5$ that in $20 \%$ casein-fed rats. Thus, the depression of erythropoiesis upon protein deprivation is primarily caused by the lowered level of erythropoietin.
\end{abstract}

The matured erythrocytes have a limited life span and cannot proliferate. These cells are recruited by differentiation and maturation of the precursor cells. Lines of evidence have accumulated indicating the presence of two populations of nonhemoglobinized progenitor cells in the erythroid pathway (reviewed in refs. 1 and 2). The colony-forming uniterythroid cells (CFU-E) are probably the direct precursors of the proerythroblasts that initiate hemoglobin synthesis. The burstforming unit-erythroid cells (BFU-E) are more primitive and are closely related to multipotent stem cells. Factors that act on BFU-E or possibly more primitive cells have been found in various sources, ${ }^{3 \sim 17)}$ but their physiological significance is not well understood. A factor referred to as erythroid-potentiating activity has been isolated from a leukemic cell line. ${ }^{18)}$ This factor enhanced the growth of BFU-E and CFU-E. Erythropoietin promotes the growth of CFU-E and the maturation process leading to the hemoglobinization of the erythroblasts.

It is widely accepted that erythropoietin, a glycoprotein with a molecular weight of $35,000,{ }^{19)}$ is the primary regulator of erythropoiesis (reviewed in ref. 20). Erythropoietin is discharged in the urine of certain anemic patients, but in very small amounts. We have

† This work was supported by Grants-in-Aid for Scientific Research from the Ministry of Education, Science and Culture of Japan.

Abbreviations: PBS, phosphate-buffered saline, $\mathrm{pH} 7.4$; BSA, bovine serum albumin. 
succeeded in raising a monoclonal antibodyproducing hybridoma against human erythropoietin $^{21)}$ and have developed a very simple isolation procedure with a high yield of this hormone from human urine using an immunoadsorbent column. ${ }^{19)}$ Several methods $\left.^{22} 25\right)$ have been developed for measuring the erythropoietin in serum, but each of them has a number of drawbacks. In vivo assays with starved rats $^{22)}$ or polycythemic mice, ${ }^{23)}$ which are believed to be the most specific for erythropoietin, are poor in precision and not sufficiently sensitive to quantify the serum erythropoietin levels of normal animals. The most convenient and sensitive assay appears to measure in vitro ${ }^{3} \mathrm{H}$-thymidine incorporation into the DNA of erythropoietinresponsive cells, ${ }^{25)}$ but it is poor in specificity since the effects of non-erythropoietin factor(s) which stimulate the DNA synthesis of nonerythroid cells in the target cell preparation are included. Also inhibitor(s) of ${ }^{3} \mathrm{H}$-thymidine incorporation are present in serum as shown in this paper.

Conditions that reduce oxygen delivery to tissues, such as anemia and hypoxia, usually cause a high level of erythropoietin in serum, while the level decreases in polycythemia by hypertransfusion. It has been shown that erythropoiesis is impaired in protein-deprived $\operatorname{animals}^{26,27)}$ and that this impairment is attributable primarily to a decrease in erythropoietin production. ${ }^{28,29)}$ The latter conclusion was deduced from data obtained by measuring the erythropoietin levels after exposing protein-deprived and -fed rats to reduced atmospheric pressure; this hypoxic stimulus increased the serum erythropoietin to the levels detectable with an in vivo assay and it was found that the increased level in protein-deprived rat was lower than that of protein-fed rats. Thus, the erythropoietin levels in sera before exposure to the stimulus as well as their dependence on dietary protein have not been investigated. Here we report a method developed for measuring the active erythropoietin levels in rat serum using the ${ }^{3} \mathrm{H}$-thymidine incorporation assay, and show that the level was substantially decreased in protein-deprived rats. A rapid decrease in serum erythropoietin by protein deprivation may suggest a novel mechanism for regulating erythropoietin production in the kidney.

\section{MATERIALS AND METHODS}

Materials. Materials were purchased from the indicated sources: components of food (Oriental Kobo), Freund's adjuvant (Difco), Affi-Gel 10 (Bio-Rad), Staphylococcus aureus (Calbiochem.), ${ }^{3} \mathrm{H}$-thymidine (Amersham International Ltd.), $\alpha$-medium (Gibco), methylcellulose (Dow Metocell, A-4M), RPMI 1640 and fetal calf serum (M.A. Bioproducts), $o$-dianisidine hydrochloride (Tokyokasei), antibiotics (Meiji Seika Co., Ltd.), 0.45 millipore filter (Millex-HA, Millipore Corporation), and sodium pentobarbital (Pitman-Moore, Inc.). BSA fraction V obtained from Sigma Chemical Co. was treated for deionization by the method of McLeod et al. ${ }^{30)}$

Food, animals and sera. The diet was composed, by weight, of $5 \%$ cellulose, $2 \%$ vitamin mixture, $6 \%$ mineral mixture, $5 \%$ sucrose and $7 \%$ soybean oil. The remainder of the food $(75 \%)$ was composed of varying amounts of casein and $\operatorname{corn} \alpha$-starch. Casein was added at the expense of starch.

The animals received food and water ad libitum. Male Wistar rats weighing $80 \mathrm{~g}$ were used for experiments to explore dietary-dependent changes in serum erythropoietin level. They were maintained on a $20 \%$ casein diet for 2 days after purchase and then fed with the defined foods for the indicated periods before withdrawing blood. Five rats were housed in one cage, four to eight groups (20 to 40 rats) being used for each experiment. Eight groups of rats were used for experiments involving low casein diets $(0,5$ and $10 \%)$ so that sufficient sera were obtained. The rats were anesthetized by injecting about $1 \mathrm{ml}$ per rat of sodium pentobarbital diluted 10-fold with PBS. Blood was withdrawn from the abdominal aorta and incubated at $37^{\circ} \mathrm{C}$ for $1 \mathrm{hr}$, then at $4^{\circ} \mathrm{C}$ for $12 \mathrm{hr}$. The serum was obtained after centrifugation and then incubated at $56^{\circ} \mathrm{C}$ for $30 \mathrm{~min}$ to inactivate the complement-dependent cytotoxic activity. The inactivated sera from rats with the same diet were combined and dialysed extensively against PBS. When rats were rendered anemic by phenylhydrazine injection to elevate the erythropoietin levels in their sera, male Wistar rats weighing $150 \mathrm{~g}$, which were maintained on a diet of commercial rat pellets, were used. They received three consecutive daily subcutaneous injections of $0.65 \mathrm{ml}$ of phenylhydrazine $(12 \mathrm{mg} / \mathrm{ml}$ in PBS $)$ per rat. On the day after the last injection, blood was withdrawn and 
the serum was prepared as already described.

Human erythropoietin. Human erythropoietin $(81,600$ units $/ \mathrm{mg}$ of protein) was isolated from the urine of anemic patients as described previously. ${ }^{19)}$ The erythropoietin solution $(1,700$ units/ml in PBS) was sterilized with a millipore filter. The sterilized solution was diluted with PBS $/ 0.1 \%$ BSA to 200 units $/ \mathrm{ml}$ and stored at $-20^{\circ} \mathrm{C}$.

Rabbit anti-human erythropoietin antiserum. Three rabbits were immunized with pure human erythropoietin by intracutaneous injection at $8 \sim 10$ sites of $320 \mu \mathrm{g}$ of erythropoietin per rabbit that was emulsified 1:1 in Freund's complete adjuvant in a total volume of $1.5 \mathrm{ml}$. Eleven days after immunization, the rabbits were injected again by the same procedures, except that $200 \mu \mathrm{g}$ of erythropoietin emulsified 1:1 in Freund's incomplete adjuvant was given intracutaneously and subcutaneously per rabbit. Two weeks after the second injection, a portion of blood was withdrawn from the ear vein of each rabbit and the sera were tested for anti-human erythropoietin activity. All of them were active, whereas preimmune sera were not. All rabbits received a second booster with $360 \mu \mathrm{g}$ of erythropoietin per rabbit in PBS without Freund's adjuvant. Eleven days after the second booster, blood was withdrawn from the carotid artery. The sera were heatinactivated at $56^{\circ} \mathrm{C}$ for $30 \mathrm{~min}$. All sera from these rabbits had anti-rat erythropoietin activity, described in Results, as well as anti-human erythropoietin activity. Here, the serum from one of them (rabbit 1), which neutralized 150 units of human erythropoietin per $\mathrm{ml}$ of the serum, was used.

Preparation of an anti-serum erythropoietin antibody column. Since the rabbit anti-human erythropoietin serum cross-reacted with rat erythropoietin, an immunoadsorbent column containing the immobilized rabbit IgG was constructed for purifying rat erythropoietin. The IgG in the serum from rabbit 1 was precipitated with a $45 \%$ saturation of ammonium sulfate, and the precipitates were purified with a DEAE-cellulose column by the method of Gravey et al. ${ }^{31)}$ The purified IgG solution $(2 \mathrm{ml}$, whose absorbance at $280 \mathrm{~nm}$ was 7.7) was extensively dialysed against $0.2 \mathrm{M} \mathrm{NaHCO}, \mathrm{pH} 8 / 0.3 \mathrm{M} \mathrm{NaCl}$. The dialysate was centrifuged at $20,000 \times g$ for $15 \mathrm{~min}$ to remove the precipitates. The IgG in the supernatant was fixed to AffiGel 10 that had been washed on a sintered glass filter three times with ice-cold isopropanol, then three times with icecold distilled water. The gel slurry (50\% in cold water) was transferred to a plastic tube and packed by centrifugation. The packed gel was mixed with an equal volume of antibody solution and rotated end over end for $12 \mathrm{hr}$ at $4^{\circ} \mathrm{C}$. The gel was washed twice with $0.1 \mathrm{M} \mathrm{NaHCO}, \mathrm{pH}$ $8 / 0.15 \mathrm{M} \mathrm{NaCl}$ to remove the uncoupled protein. The gel was mixed with an equal volume of $0.1 \mathrm{M}$ ethanolamine$\mathrm{HCl}(\mathrm{pH} 8)$ and rotated end over end for $1 \mathrm{hr}$ at room temperature to block any unreacted sites on the gel.
The slurry was washed with PBS to remove the reactants and packed in a column $(0.8 \times 2 \mathrm{~cm})$. The column was equilibrated with PBS containing $0.02 \%$ azide and stored at $4^{\circ} \mathrm{C}$ until use.

Purification of rat erythropoietin from phenylhydrazineinduced anemic rat serum with an anti-human erythropoietin antibody column. The serum $(2.5 \mathrm{ml})$ from the phenylhydrazine-induced anemic rats was put in a column containing Affi-Gel 10 on which rabbit anti-human erythropoietin antibody was fixed, and then the column was washed with $20 \mathrm{ml}$ of PBS, followed by $20 \mathrm{ml}$ of $0.15 \mathrm{M}$ $\mathrm{NaCl}$. Erythropoietin was eluted with $10 \mathrm{ml}$ of $0.2 \mathrm{M}$ acetic acid, $\mathrm{pH} 2.5 / 0.15 \mathrm{M} \mathrm{NaCl}$. The eluate was immediately neutralized with $3 \mathrm{M}$ Tris-base. After $1 \%$ BSA had been added to the neutralized solution to $0.1 \%$ in BSA concentration, the solution was extensively dialysed against PBS.

Pretreatment of rat serum by heating and ethanol precipitation. Since the erythropoietin levels in the sera of normal rats could not be determined directly as described later, pretreatment of the serum by heating and concentration of the erythropoietin by ethanol precipitation was attempted. A serum solution (about $50 \mathrm{ml}$ ) collected from the rats was chilled in a $100-\mathrm{ml}$ glass beaker with icecold water. The beaker was put into boiling water and heated for $6.5 \mathrm{~min}$. The heated sample was then chilled with ice-cold water, before erythropoietin was extracted from the heat-denatured protein lump. To the cooled sample was added cold distilled water of half the volume of the starting serum. After the sample had been rigorously homogenized in a motor-driven Teflon homogenizer, the homogenate was centrifuged at $20,000 \times g$ for $1 \mathrm{hr}$. Extraction from the precipitate was repeated with the same procedure. The protein in the combined supernatant was precipitated by adding 9 volumes of ethanol that had been chilled at $-20^{\circ} \mathrm{C}$. After standing for $12 \mathrm{hr}$ at $-20^{\circ} \mathrm{C}$, the protein precipitate was collected by centrifugation at $5,500 \times g$ for $30 \mathrm{~min}$. The soluble protein was extracted from the collected precipitate; cold PBS with a volume equal to that of the starting serum was added to the precipitate, stirring vigorously with a glass rod and centrifuging to obtain the supernatant. The extraction was done twice. Protein in the combined supernatant was precipitated again with ethanol by the same procedure. The precipitate was dissolved in $2 \sim 3 \mathrm{ml}$ of cold PBS and dialysed extensively against $\mathrm{PBS}$ at $4^{\circ} \mathrm{C}$. Quantitative measurement of the volume of each dialysate was made to calculate the concentration from serum. The dialysates were centrifuged at $40,000 \times g$ for $1 \mathrm{hr}$ to prepare clear solutions.

Cell culture. All cell culture media contained $100 \mathrm{units} / \mathrm{ml}$ of penicillin and $100 \mu \mathrm{g}$ per $\mathrm{ml}$ of streptomycin. Fetal calf serum was inactivated at $56^{\circ} \mathrm{C}$ for $30 \mathrm{~min}$. Incubation for cell culture was done at $37^{\circ} \mathrm{C}$ under a 
humidified atmosphere of $5 \% \mathrm{CO}_{2}$ in air. All cultures were made in triplicate and the data shown in this paper are the mean values.

Assay for erythropoietin. Erythropoietin was assayed by using its stimulatory effect on the DNA synthesis ${ }^{25)}$ of spleen cells from phenylhydrazine-treated mice ${ }^{32)}$ with a minor modification. BALB $/ c$ mice received two consecutive daily intraperitoneal injections of $60 \mathrm{mg}$ per $\mathrm{kg}$ of phenylhydrazine hydrochloride (a $5 \mathrm{mg} / \mathrm{ml}$ solution in PBS) to increase the number of erythropoietin-responsive erythroid cells in their spleens. On the third day after the last injection, the spleen was removed and cut into small pieces in a Petri dish containing $3 \mathrm{ml}$ of RPMI 1640 supplemented with $20 \%$ fetal calf serum, $1 \mathrm{~mm}$ pyruvate, and $2 \mathrm{~mm}$ glutamine (Medium I). The small pieces were transferred into a glass tube for centrifugation. After $10 \mathrm{ml}$ of Medium I had been added, the clumps were disrupted by gentle aspiration several times through a pipette. The suspension was left for $5 \mathrm{~min}$ to precipitate the undisrupted clumps. A single-cell suspension was obtained from the supernatant, the cells being washed twice with Medium I. The test tubes for the erythropoietin assay culture contained $375 \mu \mathrm{l}$ of the cell suspension in Medium I and a sample in PBS or PBS $/ 0.1 \% \mathrm{BSA}$, in a total volume of $500 \mu \mathrm{l}$. The samples tested for erythropoietin activity were sterilized by passing through a millipore filter. The cell concentration was $4 \times 10^{6}$ cells $/ \mathrm{ml}$, and each test tube for cell culture was capped with a sterilized aluminum cover. After $22 \mathrm{hr}$ of incubation of the culture, $0.8 \mu \mathrm{Ci}{ }^{3} \mathrm{H}$ thymidine was added to each tube, which was incubated for $2 \mathrm{hr}$ more. The incorporation of ${ }^{3} \mathrm{H}$-thymidine into DNA was measured as described previously. ${ }^{33)}$

Erythropoietin was also assayed using its stimulatory effect on erythroid colony formation in methylcellulose cultures of 13-day C57BL mouse fetal liver cells. ${ }^{34)}$ The final cell concentration was $2.5 \times 10^{4}$ cells per ml. After 2 days of culture, the erythroid colonies were stained with $o$ dianisidine (dimethoxylbenzidine) hydrochloride solution which had been freshly prepared by mixing distilled water, $2 \% \mathrm{o}$-dianisidine in $5 \%$ acetic acid, and $30 \% \mathrm{H}_{2} \mathrm{O}_{2}$ in the volume ratio of $9: 1: 0.04$. The solution $(1 \sim 2 \mathrm{ml})$ for staining was gently overlaid on the culture. After about 5 minutes, the colonies dyed deep blue containing eight or more cells were scored using an inverted microscope with a mechanical stage. The stained cells indicated hemoglobinization.

Neutralization of erythropoietin by rabbit anti-human erythropoietin antiserum. Incubations for antibody-antigen complex formation were done under sterile conditions. Two methods were tried: (1) The antibody-antigen complex was removed using protein A-bearing $S$. aureus before the erythropoietin assay. (2) The reaction mixture for the immunocomplex formation was directly assayed for erythropoietin activity. The reaction mixture for the former contained $4 \mu \mathrm{l}$ of antiserum and the samples tested in PBS or PBS $/ 0.1 \%$ BSA in a total volume of $113 \mu \mathrm{l}$. The controls contained the preimmune serum, PBS, PBS $/ 0.1 \%$ BSA instead of antiserum. After the mixture had been incubated at $37^{\circ} \mathrm{C}$ for $30 \mathrm{~min}, 33 \mu \mathrm{l}$ of a $20 \% \mathrm{~S}$. aureus suspension in PBS was added. The mixture was incubated again at $37^{\circ} \mathrm{C}$ for $30 \mathrm{~min}$ and centrifuged, before the supernatant $(125 \mu \mathrm{l})$ was assayed for erythropoietin activity. In the latter case the reaction mixture for the immunocomplex formation contained $4 \mu \mathrm{l}$ of antiserum and the samples tested in PBS or PBS $/ 0.1 \%$ BSA in a total volume of $125 \mu \mathrm{l}$. The controls contained the preimmune serum, PBS, or PBS $/ 0.1 \%$ BSA instead of the antiserum. After incubating at room temperature for about $1 \mathrm{hr}$, the mixture was assayed directly for erythropoietin activity by adding the target cell suspension. Since the two methods gave similar results, the data obtained from the latter are shown in this paper.

Protein. Protein concentration was determined with a Coomassie brilliant blue binding assay according to the manufacturer's directions (Bio-Rad) using ovalbumin as a standard.

\section{RESULTS}

\section{Stimulation of ${ }^{3} \mathrm{H}$-thymidine incorporation into DNA of cultured spleen cells by rat serum} Figure 1 shows a standard dose-response

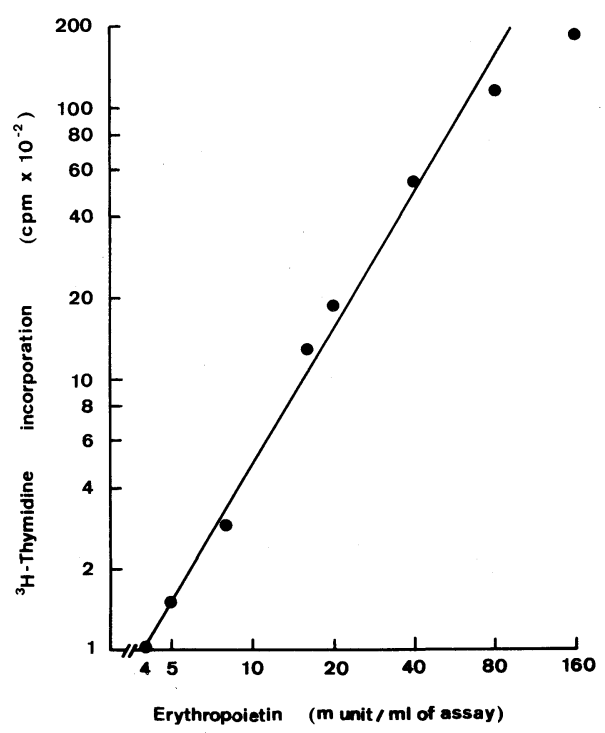

FIG. 1. Erythropoietin Dose Response Curve for ${ }^{3} \mathrm{H}-$ Thymidine Incoporation into DNA of Mouse Spleen Cells.

Pure human erythropoietin was used. Each point represents the mean of duplicates. Incorporation $(250 \mathrm{cpm})$ of the control in which PBS $/ 0.1 \%$ BSA had been added instead of erythropoietin was subtracted from the values found when the erythropoietin was added. The limit of sensitivity of this assay was about $5 \mathrm{~m}$ unit per $\mathrm{ml}$ of assay. 


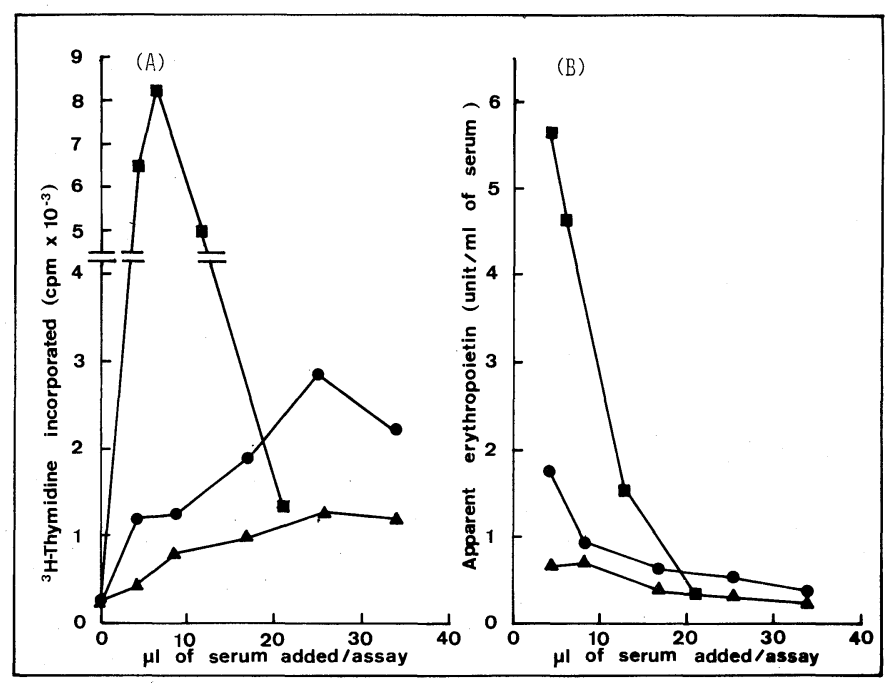

FIG. 2. - Stimulation of ${ }^{3} \mathrm{H}$-Thymidine Incorporation into DNA of Mouse Spleen Cells by Rat Sera.

(A) shows the dependence of ${ }^{3} \mathrm{H}$-thymidine incorporation on the amount of serum added to assay. The ordinate of (B) represents the erythropoitin unit per $\mathrm{ml}$ of serum, which was calculated from Fig. 1 and Fig. 2(A) on the assumption that the ${ }^{3} \mathrm{H}$-thymidine incorporation found in Fig. 2(A) was totally due to erythropoietin. Rats were maintained on a $20 \%$ casein diet or a protein-deprived diet for 7 days before withdrawing blood. The sera were incubated for inactivation of complement-dependent cytotoxic activity and then dialysed against PBS. ( $\square$ ), phenylhydrazine-induced anemic rat serum; $(\boldsymbol{\bullet}), 20 \%$ casein-fed rat serum; $(\boldsymbol{\Delta})$, protein-deprived rat serum.

curve that was drawn using phenylhydrazinetreated mouse spleen cells as targets and pure human erythropoietin as the standard. Since the dose-response curves varied when the bioassay cultures were set up on different days, the data obtained on different days were normalized by using the standard curve in Fig. 1. Figure 2(A) shows that ${ }^{3} \mathrm{H}$-thymidine incorporation into the DNA of spleen cells is stimulated by the sera from $20 \%$ casein-fed, proteindeprived, or phenylhydrazine-induced anemic rats. The incorporation increased as the sera increased in the limited volumes. The degree of stimulation was in the order of anemic, caseinfed, and protein-deprived rat sera; a high stimulation by the anemic rat serum was found. When larger volumes of the sera were added, the incorporation was rather reduced. The maximum stimulation by the anemic rat serum was seen when far less of the serum than those of casein-fed and protein-deprived rats was added. When calculations were made with the data of Fig. 2(A) to show the apparent erythropoietin levels (unit/ml of serum), however, the level was found to decrease with increasing amounts of the sera added for assay (Fig. 2(B)), indicating that the sera contained an inhibitory factor(s).

\section{Erythropoietin level in rat serum}

Table I shows the results of immunological experiments with rabbit anti-human erythropoietin antiserum. It was found that this antiserum reacted not only with human erythropoietin but also with rat erythropoietin. The stimulation of ${ }^{3} \mathrm{H}$-thymidine incorporation by the erythropoietin preparation partially purified from anemic rat serum was completely inhibited by the antibody, indicating that the stimulation was entirely due to erythropoietin in the sample and not to a non-erythropoietin factor(s). The preimmune serum did not have any effect on either human or rat erythropoietins. Stimulation by the phenylhydrazine-induced anemic rat serum was substantially attributable to erythropoietin but 
Table I. Neutralization of Erythropoietin by Rabbit Anti-Serum Erythropoietin Antiserum

Before assay by ${ }^{3} \mathrm{H}$-thymidine incorporation, samples were incubated with rabbit anti-human erythropoietin antiserum, preimmune serum, or PBS under the conditions listed in MATERIALS AND METHODS. Epo indicates erythropoietin.

\begin{tabular}{|c|c|c|c|}
\hline Sample & $\begin{array}{l}\text { Before assay, } \\
\text { samples were } \\
\text { incubated with }\end{array}$ & $\begin{array}{c}{ }^{3} \mathrm{H} \text {-Thymidine } \\
\text { incorporation } \\
(\mathrm{cpm})\end{array}$ & $\begin{array}{l}\text { Apparent Epo } \\
\text { calculated } \\
\text { (munit } / \mathrm{ml} \text { of } \\
\text { assay) }\end{array}$ \\
\hline Preimmune serum & PBS & 300 & 0 \\
\hline Antiserum & PBS & 230 & 0 \\
\hline \multirow{3}{*}{ Human Epo } & PBS & 5500 & 42 \\
\hline & Preimmune serum & 5600 & 42.4 \\
\hline & Antiserum & 280 & 0 \\
\hline \multirow{3}{*}{ Purified rat $\mathrm{Epo}^{b}$} & PBS & 3200 & 30 \\
\hline & Preimmune serum & 3100 & 29 \\
\hline & Antiserum & 290 & 0 \\
\hline \multirow{2}{*}{ Anemic rat serum ${ }^{c}$} & PBS & 13600 & 74 \\
\hline & Antiserum & 820 & 11 \\
\hline \multirow{2}{*}{ Protein-fed rat serum ${ }^{d}$} & PBS & 1850 & 20.7 \\
\hline & Antiserum & 1850 & 20.7 \\
\hline \multirow{2}{*}{ Protein-deprived rat serum ${ }^{d}$} & PBS & 1250 & 15.5 \\
\hline & Antiserum & 1300 & 16.0 \\
\hline
\end{tabular}

a Apparent erythropoietin units were calculated from Fig. 1 after subtracting the control value $(250 \mathrm{cpm})$ from each.

b Rat erythropoietin was partially purified from phenylhydrazine-induced anemic rat serum with heat treatment and alcohol precipitation.

c Phenylhydrzine-induced anemic rat serum was used without heating or alcohol precipitation.

${ }^{d}$ Rats were maintained on a $20 \%$ casein diet or a protein-deprived diet for 7 days before withdrawing blood. The sera were incubated to inactivate the complement-dependent cytotoxic activity, and were then dialysed against PBS.

$4.3 \%$ of the total ${ }^{3} \mathrm{H}$-thymidine incorporation was due to non-erythropoietin stimulatory factors. Stimulation of ${ }^{3} \mathrm{H}$-thymidine incorporation by the sera from $20 \%$ casein-fed and protein-deprived rats was not depressed by the antiserum. Thus the stimulation by these two sera was totally caused by nonerythropoietin factors. Erythropoietin in these sera may have been severely inhibited or may actually have been at low levels so that most of the ${ }^{3} \mathrm{H}$-thymidine incorporation was not due to erythropoietin. Taken together with the data of Fig. 2(B), it is clear that erythropoietin levels in normal rat sera cannot be estimated unless the sera are pretreated to remove both the inhibitory and stimulatory factors, and the erythropoietin is concentrated.

Since the rabbit anti-human erythropoietin antibody was found to crossreact with rat erythropoietin (Table I), purification and concentration of the erythropoietin from rat serum with an antibody column was first tried using anemic rat serum as the starting material (see Materials and Methods). The purified erythropoietin preparation showed a normal dose response; erythropoietin activity found in the assay mixture was proportional to the amount of added preparation (Fig. 3). Furthermore, this activity was completely neutralized by the anti-human erythropoietin antiserum (data not shown). It was found, however, that recovery of the activity was too 


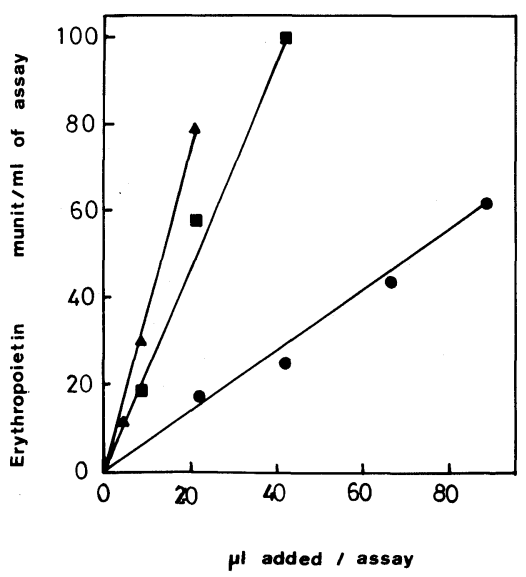

FIG. 3. Linear Dose Response of the Phenylhydrazineinduced Anemic Rat Sera Purified in Different Ways.

Erythropoietin units were calculated from the ${ }^{3} \mathrm{H}$ thymidine incorporation into DNA of mouse spleen cells and the standard curve in Fig. 1. (O) Erythropoietin in the anemic rat serum was purified with a column containing immobilized rabbit anti-human erythropoietin antibody.

(ם) The anemic rat serum was heat-treated and the supernatant obtained after centrifugation was assayed. (A) Erythropoietin in the supernatant obtained by the heat-treatment of anemic rat serum was concentrated by alcohol precipitation.

low (about $10 \%$ ) with this procedure and was not reproducible.

We then tested the dose-response curves of samples prepared from anemic rat serum by heating and subsequent alcohol precipitation (see Materials AND Methods), and also estimated the recovery of erythropoietin activity during these pretreatments. The supernatant obtained after heating gave a normal dose response (Fig. 3), indicating successful inactivation of the inhibitory factors (compare with Fig. 2(B)). The supernatant was precipitated with alcohol, and the dose response of the resulting erythropoietin preparation was normal (Fig. 3). To estimate the recovery of erythropoietin through these pretreatment procedures, the rat erythropoietin purified with an antibody column was added to the sera from casein-fed and protein-deprived rats in known amounts that were in large excess of the endogenous ${ }^{3} \mathrm{H}$-thymidine incorporation activity of the sera. The sera were treated and the recovered erythropoietin activity was mea- sured, duplicate experiments with each serum (a total of 4 replicated experiments) giving a reproducible result with a $30 \pm 5 \%$ recovery.

To estimate the serum erythropoietin levels of $20 \%$ casein-fed and protein-deprived rats, the sera were pretreated by heating and alcohol precipitation. Table II shows the results of erythropoietin activity measurements of the pretreated serum preparations and neutralization of the activity by the anti-human erythropoietin antibody. When the preparation from protein-fed rat serum was assayed, the calculated erythropoietin titers per $\mathrm{ml}$ of the assay increased with an increasing amount of the sample in the assay, although the dose response was non-linear. Furthermore, neutralization of the ${ }^{3} \mathrm{H}$-thymidine incorporating activity by the anti-human erythropoietin antiserum was incomplete, indicating the presence of some non-erythropoietin factor in the sample assayed. It was found, however, that the erythropoietin units that were neutralized by the antiserum were approximately proportional to the amount of the sample in the assay. Thus, the active erythropoietin level in $20 \%$ casein-fed rat serum can be estimated to have been $37.4 \pm 5 \mathrm{~m}$ units $/ \mathrm{ml}$ (mean \pm S.D.), taking into account the concentration effect (8.7-fold) and the activity recovery $(30 \%)$ through the pretreatment procedures. The preparation from protein-deprived rat serum showed lower ${ }^{3} \mathrm{H}$-thymidine incorporation than that from casein-fed rat serum, the incorporation being almost unchanged with increasing addition of the sample. Furthermore, no significant activity was neutralized by the antiserum. It seems that the stimulation of ${ }^{3} \mathrm{H}$-thymidine incorporation exhibited by the preparation from protein-deprived rat serum was due to a non-erythropoietin factor and the erythropoietin level was below the sensitivity limit of the assay method. The presence of an inhibitor in the preparation from protein-deprived rat serum accounting for the dose independence was excluded, because this preparation did not inhibit the activity of erythropoietin in the preparation from anemic rat serum (Table II). 
Table II. Erythropoietin Level of Rat Serum

Rats were maintained on a $20 \%$ casein diet or a protein-deprived diet for 7 days before withdrawing blood. The sera from phenylhydrazine-induced anemia, and protein-fed and protein-deprived rats were pretreated by heating and alcohol precipitation as described in MATERIALS AND METHODS. Epo indicates erythropoietin.

\begin{tabular}{|c|c|c|c|c|}
\hline $\begin{array}{c}\text { Pretreated } \\
\text { sera supply }\end{array}$ & $\begin{array}{c}\text { Before assay, } \\
\text { sera were } \\
\text { incubated with }\end{array}$ & $\begin{array}{c}\text { Volume added } \\
\text { to assay } \\
(\mu \mathrm{l})\end{array}$ & $\begin{array}{c}{ }^{3} \mathrm{H} \text {-Thymidine } \\
\text { incorporation } \\
(\mathrm{cpm})\end{array}$ & $\begin{array}{c}\text { Epo } \\
(\mathrm{m} \text { unit } / \mathrm{ml}) \\
{\text { of assay })^{b}}^{\text {of }}\end{array}$ \\
\hline \multirow{6}{*}{ Protein-fed rats } & \multirow{3}{*}{ PBS } & 42 & 950 & - \\
\hline & & 84 & 1670 & - \\
\hline & & 126 & 3000 & - \\
\hline & \multirow{3}{*}{ Antiserum } & 42 & 620 & 8 \\
\hline & & 84 & 820 & 14 \\
\hline & & 126 & 1420 & 28 \\
\hline \multirow{4}{*}{ Protein-deprived rats } & \multirow{3}{*}{ PBS } & 42 & 380 & - \\
\hline & & 84 & 360 & - \\
\hline & & 126 & 370 & - \\
\hline & Antiserum & 126 & 320 & \\
\hline Anemic rats & & 8.3 & 4100 & - \\
\hline Anemic rats & & 8.3 & & \\
\hline$\stackrel{+}{+}$ Protein-deprived rats & & $\begin{array}{l}+ \\
84.0\end{array}$ & 3980 & - \\
\hline
\end{tabular}

a Before the assay by ${ }^{3} \mathrm{H}$-thymidine incorporation, the pretreated sera were incubated with rabbit anti-human erythropoietin antiserum or PBS under the conditions described in MATERIALS AND METHODS.

${ }^{b} \quad{ }^{3} \mathrm{H}$-Thymidine incorporation due to erythropoietin was calculated by subtracting the value obtained with the antiserum-treated sample from that of the PBS-treated sample. Erythropoietin units were calculated from Fig. 1.

Both samples prepared by pretreating the sera of $20 \%$ casein-fed and protein-deprived rats were also assayed by scoring erythroid colonies in a methylcellulose culture using fetal mouse liver cells as targets. Table III shows the results. When the sample from the $20 \%$ caseinfed rat serum was tested, a number of erythroid colonies over the control ( $23 \pm 6$ colonies) was formed, increasing as the sample was increased. Erythropoietin in the serum was calculated to be about $33 \mathrm{~m}$ units $/ \mathrm{ml}$, in good agreement with the ${ }^{3} \mathrm{H}$-thymidine incorporation method. The sample from the proteindeprived rat serum showed no significant stimulation of the colony formation.

We conclude from these results that biologically active erythropoietin in rat serum greatly decreases with protein deprivation in the diet. The level in protein-deprived rat serum would be lower than $1 / 10$ that of protein-fed rats. Thus, we have developed a method which allows the dietary protein-dependent changes of bioactive erythropoietin in serum to be followed, although laborious and careful pretreatments of the serum were required.

\section{Dietary protein-induced change of erythro- poietin level}

To examine the effects of the protein content of the diet on erythropoietin levels, rats were given food containing fixed amounts of casein for 7 days. Figure 4 shows the results, including the dietary-induced change of serum protein concentration. The erythropoietin in serum increased as the protein content increased from an undetectable level (lower than $4 \mathrm{~m}$ units $/ \mathrm{ml}$ ) with protein deprivation to $35 \mathrm{~m}$ units $/ \mathrm{ml}$ with the $20 \%$ casein diet. The level reached a plateau with diets containing more casein than $20 \%$. The serum protein concentration remained constant $(75 \mathrm{mg} / \mathrm{ml})$ on diets with $20 \sim 75 \%$ casein contents, but de- 
Table III. Erythropoietin Level of Rat Serum ASSAYEd By THE ERYTHROID COLONY FORMATION METHOD

The rat sera were the same as in Table II. The procedures for methylcellulose culture have been reported $^{34)}$ and are described briefly in MATERIALS AND Methods. Epo indicates erythropoietin.

\begin{tabular}{lcc}
\hline Sample & $\begin{array}{c}\text { Addition .to } \\
\text { culture }\end{array}$ & $\begin{array}{c}\text { Number of erythroid } \\
\text { colonies/culture }\end{array}$ \\
\hline & (m unit) & \\
& 0 & $23 \pm 6$ \\
Human Epo & 3.8 & $39 \pm 8$ \\
& 8.0 & $55 \pm 10$ \\
& 16.0 & $83 \pm 9$ \\
Pretreated serum & 175 & $48 \pm 9$ \\
from protein-fed & 350 & $76 \pm 10$ \\
rats & $(\mu \mathrm{l})$ & \\
\hline & & \\
$\begin{array}{l}\text { Pretreated serum } \\
\text { from protein- } \\
\text { deprived rats }\end{array}$ & 350 & $27 \pm 4$ \\
\hline
\end{tabular}

Mean values \pm S.D. are given. creased to $67 \%$ with protein deprivation.

The course of the erythropoietin decrease after the start of protein deprivation is shown in Fig. 5. The erythropoietin decreased to about $20 \%$ after protein deprivation for $12 \mathrm{hr}$ and afterwards to a level below the limit of the sensitivity of the present assay. The serum protein concentration did not show a significant change within the period tested (see also Fig. 5).

\section{Sephadex G-150 chromatography of $20 \%$ casein-fed rat serum}

Although it has been claimed that the ${ }^{3} \mathrm{H}$ thymidine incorporation assay method using phenylhydrazine-induced mouse spleen cells as the target is much less influenced by the levels of non-erythropoietin stimulatory factors in normal human plasma than is the ${ }^{59} \mathrm{Fe}$ incorporation method, and that the ${ }^{3} \mathrm{H}$ thymidine method can assay erythropoietin directly in the plasma, ${ }^{32)}$ our results demonstrate the presence of such non-erythro-

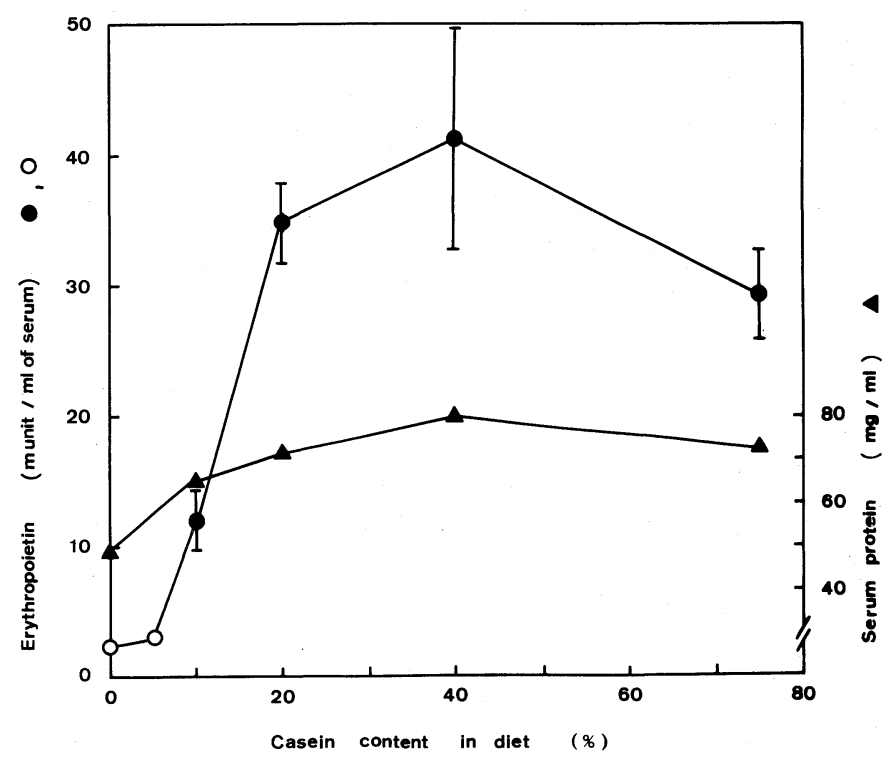

Fig. 4. Dependence of Erythropoietin Level on the Dietary Casein Content.

Rats were maintained on food containing varied amounts of casein for 7 days. The sera were pretreated by heating and alcohol precipitation as described in MATERIALS AND METHODS. Erythropoietin was assayed by the ${ }^{3} \mathrm{H}$-thymidine incorporation method. The erythropoietin in each serum was calculated as described in Table II; ${ }^{3} \mathrm{H}$-thymidine incorporporation due to erythropoietin was calculated by subtracting the value obtained with the antiserum-treated sample from that with the PBS-treated sample, the resulting value being converted to erythropoietin units using Fig. 1. $(\odot, \bigcirc)$ erythropoietin; $(\triangle)$ serum protein. Erythropoietin units less than the limit of sensitivity of this assay are given as open circles. 


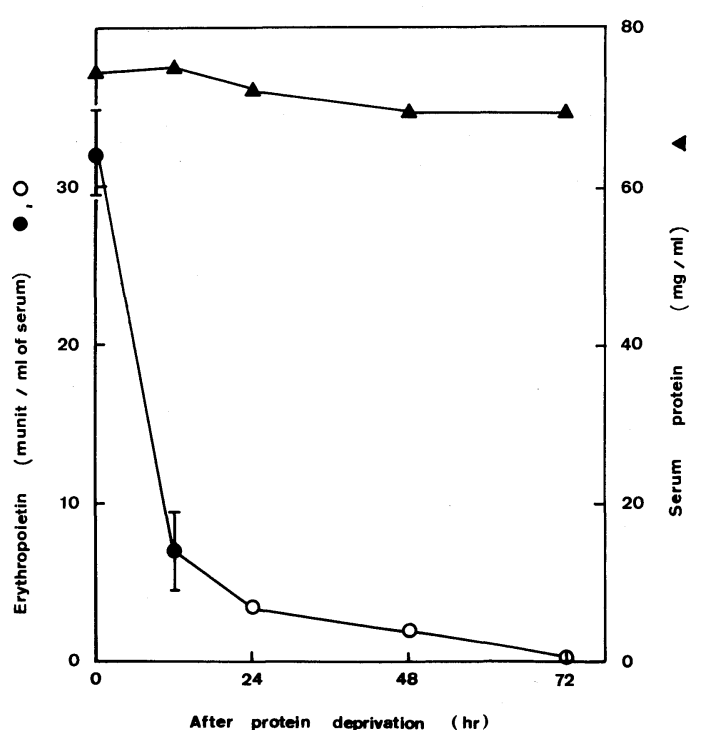

FIG. 5. Course of Erythropoietin Decrease in Serum after Protein Deprivation.

Rats were maintained on the protein-deprived diet for the indicated periods. All other procedures were as described in the legend of Fig. 4. (O, O) Erythropoietin; $(\boldsymbol{\Delta})$ serum protein. Erythropoietin units less than the limit of sensitivity of the present assay are given as open circles.

poietin factors, including inhibitory ones, in rat serum that make a direct assay impossible. The presence of these factors was further explored with Sephadex G-150 column chromatography. Figure 6 shows the results when $2 \mathrm{ml}$ of the casein-fed rat serum was put on a column. The activity of ${ }^{3} \mathrm{H}$-thymidine incorporation was found in fractions $50 \sim 75$. The total activity in these fractions was approximately $1,700 \mathrm{~m}$ units $/ \mathrm{ml}$, resulting in $850 \mathrm{~m}$ units $/ \mathrm{ml}$ of the serum. It has not been tested whether or not this activity is neutralized by the anti-erythropoietin antiserum but almost all of the activity is probably exhibited by nonerythropoietin factors because the true erythropoietin level is about $1 / 25$ of this value. The activity due to non-erythropoietin factors was also reduced to $1 / 5$ in protein-deprived rat serum (data not shown). The molecular weight of rat erythropoietin was calculated to be 65,000 from the elution position of erythropoietin purified from anemic rat serum. An elution pattern of inhibitors was depicted by measuring the ${ }^{3} \mathrm{H}$-thymidine incorporation caused by samples containing a known amount of exogeneously added erythropoietin and a constant volume of each fraction. The pattern indicates the presence of inhibitors with a wide range of molecular weights. A similar distribution pattern of inhibitors was obtained with the protein-deprived rat serum (data not shown).

\section{DISCUSSION}

No assay method with sufficient sensitivity to allow the estimation of subnormal erythropoietin levels in serum without pretreatment of the serum has been developed, although it has become crucial for both clinical and basic research in the field of erythropoiesis. Radioimmunoassay, a very promising technique for measuring small amount of hormones, has been tried in several laboratories $^{35 \sim 39)}$ but one of the difficulties always encountered appears to be the lack of pure erythropoietin and, inevitably, enough antiserum to routinely perform this assay. The isolation method of erythropoietin with a high yield developed in this laboratory would remove this limitation. ${ }^{19)}$ The efforts to assay erythropoietin have been devoted to human sera and, therefore, no paper has appeared describing procedures to permit the quantitative measurement of erythropoietin levels, especially subnormal levels, in other animal sera. This has prevented us from studying the mechanism of impairment of erythropoiesis by dietary protein deprivation. The pretreatment of rat serum before the assay presented in this paper, although it was laborious and had to be done very cautiously for reproducible results, has made it possible to reveal dietary proteininduced changes of bioactive erythropoietin levels in rat serum. Rat serum contained inhibitory factors when it was assayed by ${ }^{3} \mathrm{H}$ thymidine incorporation into DNA of mouse spleen cells (Figs. 2B and 6). These factors could have been completely inactivated by heating the serum so that no inhibitory effect was found in the pretreated sera (Fig. 3 and Table II). Inhibitory factors of different sizes 


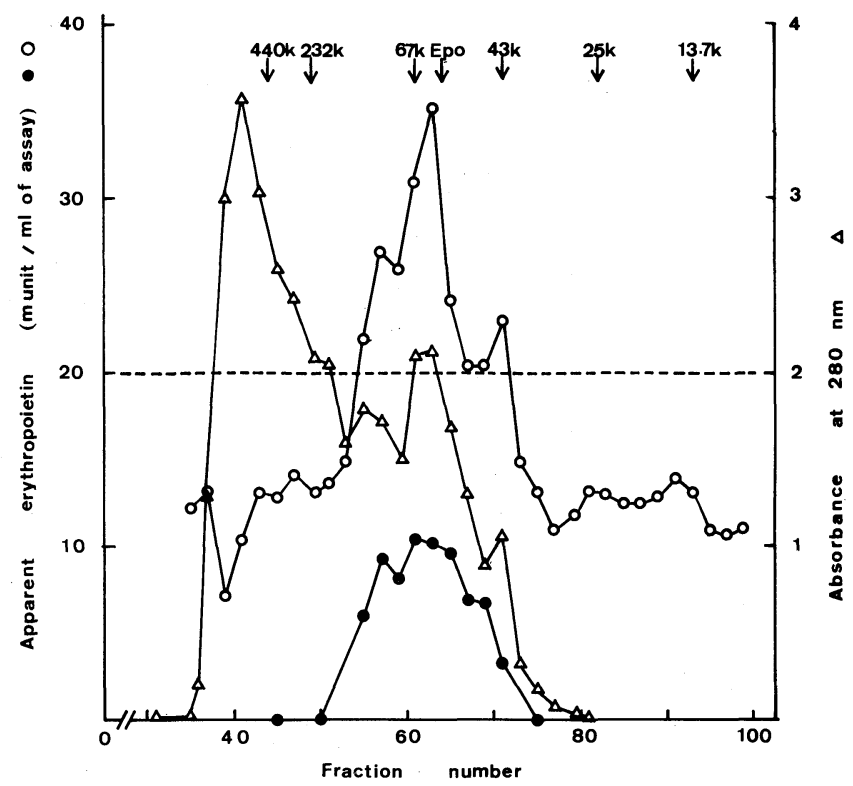

FIG. 6. Sephadex G-150 Chromatography of Protein-fed Rat Serum.

Two $\mathrm{ml}$ of protein-fed rat serum was put on a Sephadex G-150 column $(1.6 \times 50 \mathrm{~cm})$ equilibrated with PBS containing $0.1 \%$ BSA $(O, O)$. When the experiment was done to depict the elution pattern of protein by measuring absorbance at $280 \mathrm{~nm}$, BSA in the equilibrium buffer was omitted $(\triangle)$. The column was developed at $4^{\circ} \mathrm{C}$ with a speed of $9.5 \mathrm{ml}$ per hour. The volume of each fraction was $1 \mathrm{ml}$. The elution position of rat erythropoietin was determined with the preparation purified from anemic rat serum by using the antibody column.

Apparent erythropoietin units were calculated from ${ }^{3} \mathrm{H}$-thymidine incorporation into DNA of mouse spleen cells and the standard curve in Fig. 1.

(O) ${ }^{3} \mathrm{H}$-thymidine incorporation was measured with $42 \mu \mathrm{l}$ of each fraction. ( $\left.\bigcirc\right){ }^{3} \mathrm{H}$-thymidine incorporation was measured with $42 \mu \mathrm{l}$ of each fraction in the assay containing pure human erythropoietin at $20 \mathrm{~m}$ units per $\mathrm{ml}$ of assay. the presence of an inhibitory substance could easily be found by looking for the fractions which had fewer than $20 \mathrm{~m}$ units of erythropoietin per $\mathrm{ml}$ of assay.

(Fig. 6) were found in both protein-fed rat serum and protein-deprived serum. The effects of dietary protein on these inhibitors cannot be discussed here because a quantitative comparison of the inhibitory activity between the sera has not been made, and further it is unknown whether or not these factors have physiological functions in the regulation of rat erythropoiesis. Inhibitory factors were found in unfractionated human serum when the erythropoietin was assayed by the ${ }^{59} \mathrm{Fe}$ incorporation method. ${ }^{40)}$ Rat serum also had nonerythropoietin factors which stimulated ${ }^{3} \mathrm{H}$ thymidine incorporation into DNA of spleen cells (see Table I). The target spleen cell preparation contained not only erythropoietinresponsive erythroid precursors but also nonerythroid cells such as granulocytes and lym- phocytes. It is likely that the serum contained factors stimulating DNA synthesis of the cells other than erythropoietin-sensitive cells. The factors appear to be fairly resistant to heating and were still present in the pretreated sera (Table II). The difficulty in erythropoietin measurement arising from these remnants was overcome using the antibody against the pure human erythropoietin (Table II). The physiological functions of such factors are also unknown.

The erythropoietin level increased with increasing protein content in the diet up to $20 \%$ and afterwards did not change significantly, although the protein content was increased. The constant level of erythropoietin would be very important physiologicaly to avoid erythrocytosis, although the mechanism for keeping 
the constant level remains to be investigated. The kidney is mainly responsible for erythropoietin production ${ }^{20,41)}$ but the control mechanism for production is not well understood.

It has been shown with rats weighing $100 \mathrm{~g}$ that the rate of ${ }^{59} \mathrm{Fe}$ incorporation into circulating erythroid cells decreases to $1 / 5$ that of protein-fed rats after protein deprivation for 2 days. $^{27)}$ The decreased formation of the circulating erythroid cells was preceded by a decrease in the erythropoietin level; the level decreased to $1 / 5$ that of the protein-fed rats after $12 \mathrm{hr}$ of protein deprivation (Fig. 5). This indicates that the impairment of erythropoiesis by protein deficiency is caused by the lowered levels of erythropoietin.

The half-life of erythropoietin in rat serum was calculated from Fig. 5 to be about $6.3 \mathrm{hr}$, if it was assumed that the erythropoietin production ceased abruptly with the start of protein deprivation and the rate of breakdown was unchanged. Human ${ }^{125} \mathrm{I}$-labeled erythropoietin had a plasma half-life of $3.5 \mathrm{hr}$ in normal rats. ${ }^{42)}$ The erythropoietin decrease evoked by protein deprivation was probably due to the decrease in erythropoietin production, although the possibility cannot be excluded that the breakdown of erythropoietin was elevated. The rapid protein deprivationinduced decrease in erythropoietin level (Fig. 5) suggests an immediate depression of production after the deprivation and does not seem explainable by an insufficient supply of amino acids as building materials required for erythropoietin synthesis to the kidney cells responsible for the erythropoietin production. Certain amino acids may function as a signal to the kidney cells to switch on erythropoietin production, including secretion of alreadysynthesized erythropoietin into the bloodstream. Surveying the amino acids in the diet needed to keep the erythropoietin at the level of protein-fed rats is in progress.

\section{REFERENCES}

1) J. L. Spivak and S. E. Graber, The Johns Hopkins
Medical Journal, 146, 311 (1980).

2) M. Ogawa, P. N. Porter and T. Nakahata, Blood, 61, 823 (1983)

3) M. T. Aye, J. Cell. Physiol., 91, 69 (1977).

4) G. R. Johnson and D. Metcalf, Proc. Natl. Acad. Sci. U.S.A., 74, 3879 (1977).

5) N. N. Iscove, "Hematopoietic Cell Differentiation," Vol. 10, ed. by D. W. Golde, M. J. Cline, D. Metcalf and C. F. Fox, ICN-UCLA Symposia on Molecular and Cellular Biology, Academic Press, New York, 1978, p. 37.

6) D. G. Nathan, L. Chess, D. G. Hillman, B. Clarke, J. Breard, E. Merler and D. E. Housman, J. Exp. Med., 117, 322 (1979).

7) D. M. Meytes, A. Ma, J. A. Ortega, N. A. Shore and P. P. Dukes, Blood, 54, 1050 (1979).

8) D. W. Golde, N. Bersch, S. G. Quan and A. J. Lusis, Proc. Natl. Acad. Sci. U.S.A., 77, 593 (1980).

9) K. S. Zuckerman, Exp. Hematol., 8, 924 (1980).

10) J. I. Kurland, P. A. Meyers and M. A. S. Moor, J. Exp. Med., 151, 839 (1980).

11) P. P. Dukes, A. Ma and D. Meytes, Exp. Hematol., 8, supplement No. 8, 128 (1980).

12) J. L. Ascensao, N. E. Key, T. Earenfight-Engler, H. S. Koren and E. D. Zanjani, Blood, 57, 170 (1981).

13) L. I. Gordon, W. J. Miller, R. F. Branda, E. D. Zanjani and H. S. Jacob, Blood, 55, 1047 (1980).

14) E. D. Werts, R. L. DeGowin, S. K. Knapp and D. P. Gibson, Exp. Hematol., 8, 423 (1980).

15) P. N. Porter and M. Ogawa, Blood, 59, 1207 (1982).

16) T.Okamoto, A. Kanamaru, H. Hara and K. Nagai, Exp. Hematol., 10, 844 (1982).

17) K. S. Zuckerman, V. R. Patel and D. D. Goodrum, Exp. Hematol., 11, 475 (1983).

18) C. A. Westbrook, J. C. Gasson, S. E. Gerber, M. E. Selsted and D. W. Golde, J. Biol. Chem., 259, 9992 (1984).

19) S. Yanagawa, K. Hirade, H. Ohnota, R. Sasaki, H. Chiba, M. Ueda, and M. Goto, J. Biol. Chem., 259. 2707 (1984).

20) J. W. Fisher, Proc. Soc. Exp. Biol. Med., 173, 289 (1983).

21) S. Yanagawa, S. Yokoyama, K. Hirade, R. Sasaki, H. Chiba, M. Ueda and M. Goto, Blood, 64, 357 (1984).

22) W. Fried, L. F. Plzak, L. O. Jacobson and E. Goldwasser, Proc. Soc Exp. Biol. Med., 94, 237 (1957).

23) P. M. Cotes and D. R. Bangham, Nature, 191, 1065 (1961).

24) J. R. Stephenson and A. A. Axelrad, Endocrinology, 88, 1519 (1971).

25) N. C. Brandan, P. M. Cotes and J. Espada, Brit. J. Haematol., 47, 461 (1981).

26) A. U. Orten and A. H. Smith, Am. J. Physiol., 119, 381 (1937).

27) K. R. Reissmann, Blood, 23, 137 (1964). 
28) K. R. Reissmann, Blood, 23, 146 (1964).

29) A. Anagnostou, S. Schade, M. Ashkinaz, J. Barone and W. Fried, Blood, 50, 1093 (1977).

30) D. L. McLeod, M. M. Shreeve and A. A. Axelrad, "In Vitro Aspects of Erythropoiesis," ed. by M. J. Murphy, Jr., Springer-Verlag, New York, 1978, p. 31.

31) J. S. Gravey, N. E. Cremer and D. H. Sussdorf, "Methods in Immunol.," 3rd ed., W. A. Benzamin, Inc., Massachusetts, 1977, p. 223.

32) G. Krystal, Exp. Hematol., 11, 649 (1983).

33) S. Yanagawa, H. Narita, R. Sasaki, H. Chiba, N. Itada and H. Okada, Agric. Biol. Chem., 47, 1311 (1983).

34) T. Okamoto, A. Kanamaru, H. Hara and K. Nagai, Am. J. Hematol., 12, 179 (1982).
35) J. W. Sherwood and E. Goldwasser, Blood, 54, 885 (1979).

36) C. G. Zaroulis, B. J. Hoffman and I. A. Kourides, Am. J. Hematol., 11, 85 (1981).

37) J. F. Garcia, S. N. Ebbe, L. Hollander, H. O. Cutting, M. E. Miller and E. P. Cronkite, J. Lab. Clin. Med., 99, 624 (1982).

38) A. B. Rege, J. Brookins and J. W. Fisher, J. Lab. Clin. Med., 100, 829 (1982).

39) P. M. Cotes, Brit. J. Haematol., 50, 427 (1982).

40) G. Krystal, A. C. Eaves and C. J. Eaves, J. Lab. Clin. Med., 97, 158 (1981).

41) W. Jelkmann, A. Kurtz and C. Bauer, Exp. Hematol., 11, 581 (1983).

42) D. S. Emmanouel, E. Goldwasser and A. I. Katz, Am. J. Physiol., 247, F168 (1984). 